Bangladesh J. Bot. 38(1): 39-46, 2009 (June)

\title{
AIRBORNE POLLEN GRAINS AT CHITTAGONG UNIVERSITY CAMPUS, BANGLADESH
}

\author{
M.K. Pasha and Mohammad Sohrab Hossain
}

Department of Botany, University of Chittagong, Chittagong-4331, Bangladesh

E-mail: pashamk49@yahoo.com

Key words: Airborne, Pollen grains, Palynology, Chittagong Univ. Campus, Bangladesh

\begin{abstract}
A total of 4,549 airborne pollen grains were recorded and classified into 34 pollen morpho-types in an airborne pollen survey at Chittagong University campus, during October, 2006 to September 2007. Maximum contribution was made by Poaceae type (32.89\%), followed by Cyperaceae (5.94\%), Mesua nagassarium (3.98\%), Amaranthaceae (3.72\%), Mimosaceae (3.58\%), Artocarpus heterophyllus (2.75\%), Cocos nucifera $(2.73 \%)$, Asteraceae $(2.95 \%)$ and some other types specific to this region. The unidentified pollen contributed to an average of $16.90 \%$. Maximum pollen concentration was observed in the month of March $(20.27 \%)$ and minimum in July (2.70\%).
\end{abstract}

\section{Introduction}

Pollen and spores are the common airborne biological materials and can be detected throughout the year (Pasha 2003). Early attempt related to aeropalynology in Bangladesh, from Chittagong was by Badya (1989) and Badya and Pasha (1991). Since then a considerable changes have occurred in the vegetation of the region, and thus an aerobiological investigation was a necessity. The present investigation is expected to add more data about the qualitative and quantitative occurrence of pollen grains in the atmosphere of Chittagong University Campus in terms of their role as organic environmental pollutants.

\section{Materials and Methods}

The Chittagong University Campus was selected as sampling area. The Campus is situated between the latitude $22^{\circ} 24^{\prime \prime}$ North and longitude $91^{\circ} 50^{\prime \prime}$ East. It is located about $16 \mathrm{~km}$ north of Chittagong Metropolitan City and about $3 \mathrm{~km}$ south-west of the Hathazari Upazilla headquarter, about $2 \mathrm{~km}$ west of the Chittagong-Rangamati Road. Due to continuous destruction year after year, the original species of plants have disappeared from all places except some fallow and protected areas. During the last three decades of afforestation, many of the areas are now covered by trees with intersected fallow and occasional agricultural lands. The physiography of the area is highly undulated.

The airborne pollen survey was carried out by Gregory's Sampler method (Gregory 1961). This sampler is grouped under impaction method using vertical wind movement and inclined glass slide. From October, 2006 to September, 2007, two slides smeared with glycerine jelly, were placed daily in Gregory's Sampler on the root of a $10 \mathrm{~m}$ height building. Here, fast green was used to stain the jelly during its preparation. With an interval of every 24 hours, the slides were collected from the trap and covered with $18 \mathrm{~mm} \times 18 \mathrm{~mm}$ cover glass. The covered areas were examined under microscope instantly or within a few days afterwards. The trapped pollen grains were studied on daily, monthly, seasonaly and then yearly basis. Pollen identification was made on the basis of the reference slides from the Pollenotheca placed in the Palynology laboratory, in the Department of Botany, Chittagong University and also the relevant published literatures. 


\section{Results and Discussion}

A total of 4,549 pollen grains were trapped, which were classified into 34 pollen morphotypes (Table 1, Plate 1). These were further classified into identified and unidentified types. The pollen grains identified up to family, genus or species level were considered as identified type. The identified types belonged to ten families, three genera and 20 species. Of the identified pollen types, Poaceae contributed the highest number (32.89\%), followed by Cyperaceae (5.94\%). The other dominant types under the species or family were Mesua nagassarium (3.98\%), Amaranthaceae (3.72\%), Mimosaceae (3.58\%), Artocarpus heterophyllus (2.75\%), Cocos nucifera $(2.73 \%)$, Asteraceae $(2.95 \%)$ and a few other minor types specific to this region. The unidentified pollen types were about 16.90 per cent.
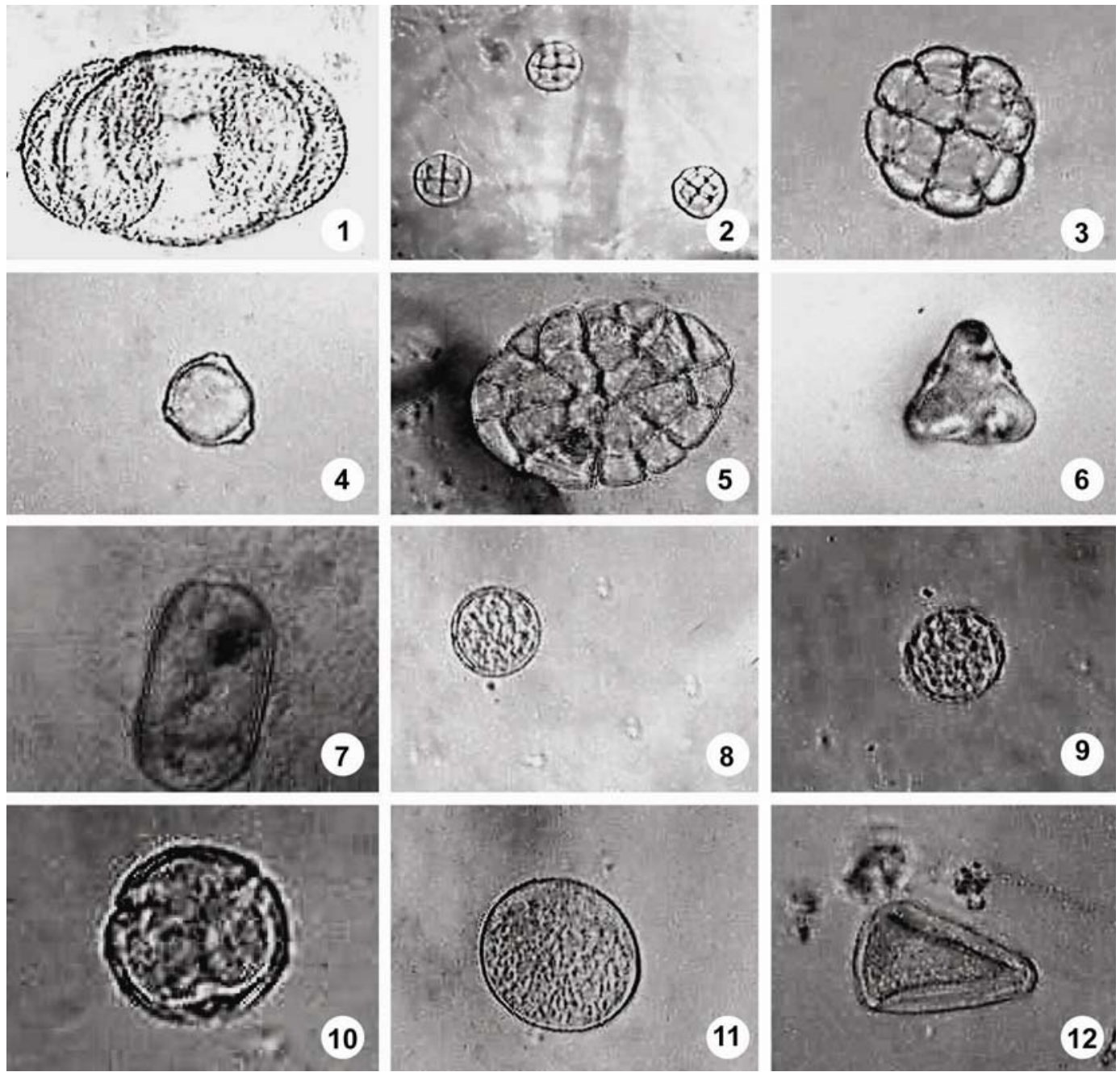

Plate 1. Some of the commonly trapped airborne pollen morphoforms at Chittagong University Campus. Figs. 1-12: 1. Pinus sp. (S.V.), 2. Acacia auriculiformis (S.V.), 3. Acacia catechuoides(S.V.), 4. Mesua nagassarium (S.V.), 5. Samanea saman (S.V.), 6. Bombax insigne (P.V.), 7. Adhatoda vasica(E.V.), 8. Amaranthus spinosus (E.V.), 9. Chenopodium album(E.V.), 10. Ixora sp. (P.V.), 11. Poaceae (E.V.), 12. Cyperaceae (E.V.). (Figs. magnified $\times 500 ;$ S.V. = Side view; P.V. = Polar view; E.V. = Equatorial view). 
Table 1. Source of airborne pollen grains, monthly variation and their incidence at Chittagong University Campus.

\begin{tabular}{|c|c|c|c|c|c|c|c|c|c|c|c|c|c|c|c|}
\hline \multirow{2}{*}{\multicolumn{2}{|c|}{$\begin{array}{l}\text { Sl. Pollen source } \\
\text { No. }\end{array}$}} & \multicolumn{12}{|c|}{ Months with total pollen count } & \multirow{2}{*}{$\begin{array}{l}\text { Total } \\
\text { count }\end{array}$} & \multirow[t]{2}{*}{ Per cent } \\
\hline & & Oct. & Nov. & Dec. & Jan. & Feb. & Mar. & Apr. & May. & Jun. & Jul. & Aug. & Sep. & & \\
\hline \multicolumn{16}{|c|}{ Gymnosperm } \\
\hline 1 & Pinus sp. & - & - & 3 & 30 & 7 & - & - & - & - & - & 0 & 0 & 40 & 0.88 \\
\hline \multicolumn{16}{|c|}{ Angiosperms (compound pollens) } \\
\hline 1 & $\begin{array}{l}\text { Acacia } \\
\text { auriculiformis }\end{array}$ & 15 & 40 & 21 & - & - & - & - & - & - & - & 7 & 10 & 93 & 2.04 \\
\hline 2 & $\begin{array}{l}\text { Acacia } \\
\text { catechuoides }\end{array}$ & - & - & - & - & - & - & - & 10 & 20 & 9 & 0 & 0 & 39 & 0.86 \\
\hline 3 & Albizzia lebbeck & - & - & - & - & - & - & 1 & - & - & - & 0 & 0 & 1 & 0.02 \\
\hline 4 & Samanea saman & - & - & - & - & - & - & 22 & 12 & 5 & - & 0 & 0 & 39 & 0.86 \\
\hline \multicolumn{16}{|c|}{ Angiosperms (simple pollens) } \\
\hline 1 & Adhatoda vasica & - & - & - & - & - & 7 & - & - & - & - & 0 & 0 & 7 & 0.15 \\
\hline 2 & $\begin{array}{l}\text { Amaranthus } \\
\text { spinosus }\end{array}$ & 13 & 23 & - & - & - & 2 & 9 & 2 & - & - & 2 & 9 & 60 & 1.32 \\
\hline 3 & $\begin{array}{l}\text { Amaranthus } \\
\text { virdis }\end{array}$ & - & - & - & - & 4 & 8 & - & 3 & 1 & - & 5 & 4 & 25 & 0.55 \\
\hline 4 & $\begin{array}{l}\text { Artocarpus } \\
\text { heterophyllus }\end{array}$ & - & - & - & - & 34 & 89 & 2 & - & - & - & 0 & 0 & 125 & 2.75 \\
\hline 5 & $\begin{array}{l}\text { Barringtonia } \\
\text { acutangula }\end{array}$ & - & - & - & - & - & - & - & 2 & 8 & - & 0 & 0 & 10 & 0.22 \\
\hline 6 & Bombax insigne & - & - & - & 5 & 4 & - & - & - & - & - & 0 & 0 & 9 & 0.20 \\
\hline 7 & $\begin{array}{l}\text { Butea } \\
\text { monnosperma }\end{array}$ & - & - & - & - & 11 & 33 & - & - & - & - & 0 & 0 & 44 & 0.97 \\
\hline 8 & Cassia siamea & - & - & - & 4 & 35 & 14 & - & - & 4 & 9 & 3 & 0 & 69 & 1.52 \\
\hline 9 & $\begin{array}{l}\text { Chenopodium } \\
\text { album }\end{array}$ & - & - & - & - & - & 12 & 2 & 7 & - & - & 0 & 0 & 21 & 0.46 \\
\hline 10 & Cocos nucifera & 3 & - & 14 & 17 & 28 & 8 & 3 & 3 & 29 & - & 7 & 12 & 124 & 2.73 \\
\hline 11 & $\begin{array}{l}\text { Embelica } \\
\text { officinalis }\end{array}$ & - & - & - & - & - & 69 & 3 & 11 & - & - & 0 & 0 & 83 & 1.82 \\
\hline 12 & $\begin{array}{l}\text { Kyllinga } \\
\text { monocephala }\end{array}$ & - & - & - & - & -- & - & - & 11 & 5 & - & 3 & 0 & 19 & 0.42 \\
\hline 13 & Mangifera indica & - & - & - & - & 20 & 27 & - & - & - & - & 0 & 0 & 47 & 1.03 \\
\hline 14 & $\begin{array}{l}\text { Mesua } \\
\text { nagassarium }\end{array}$ & - & - & - & - & 76 & 91 & 12 & 2 & - & - & 0 & 0 & 181 & 3.98 \\
\hline 15 & $\begin{array}{l}\text { Mikania } \\
\text { scandens }\end{array}$ & - & 20 & 31 & 18 & - & - & - & - & - & - & 0 & 0 & 69 & 1.52 \\
\hline 16 & Moringa oleifera & - & - & - & - & 26 & 12 & - & - & - & - & 0 & 0 & 38 & 0.84 \\
\hline 17 & Citrus spp. & - & - & - & 1 & 8 & 10 & 3 & 3 & 4 & - & 11 & 0 & 40 & 0.88 \\
\hline 18 & Ixora spp. & - & - & - & 2 & - & 10 & 3 & 2 & 4 & - & 9 & 3 & 33 & 0.73 \\
\hline 19 & Amaranthaceae & 11 & 19 & 24 & 20 & 31 & 24 & 3 & 9 & 3 & - & 8 & 17 & 169 & 3.72 \\
\hline 20 & Arecaceae & 4 & 7 & 4 & 21 & 14 & 22 & - & 6 & 8 & 2 & 3 & 7 & 98 & 2.15 \\
\hline 21 & Asteraceae & 28 & 21 & 11 & 21 & 7 & 8 & - & 7 & - & 1 & 18 & 12 & 134 & 2.95 \\
\hline 22 & Bombacaceae & - & - & 7 & 23 & 9 & 3 & - & - & - & - & 0 & 0 & 42 & 0.92 \\
\hline 23 & Caesalpiniaceae & - & - & 2 & 14 & 19 & 19 & 4 & 7 & 7 & - & 4 & 0 & 76 & 1.67 \\
\hline 24 & Cyperaceae & - & - & 9 & 16 & 53 & 46 & 8 & 41 & 48 & 29 & 18 & 2 & 270 & 5.94 \\
\hline 25 & Euphorbiaceae & - & - & - & 2 & 4 & 19 & - & 7 & 4 & - & 3 & 0 & 39 & 0.86 \\
\hline 26 & Lamiaceae & 7 & 4 & 2 & 5 & 7 & 22 & - & 5 & 7 & - & 13 & 5 & 77 & 1.69 \\
\hline 27 & Mimosaceae & 12 & 20 & 8 & 48 & - & 19 & - & 12 & 23 & 1 & 14 & 6 & 163 & 3.58 \\
\hline 28 & Poaceae & 43 & 78 & 244 & 248 & 254 & 192 & 73 & 94 & 164 & 39 & 46 & 21 & 1496 & 32.89 \\
\hline 29 & Unidentified & 30 & 70 & 45 & 136 & 104 & 156 & 23 & 56 & 31 & 33 & 47 & 38 & 769 & 16.90 \\
\hline & Monthly total & 166 & 302 & 425 & 631 & 755 & 922 & 171 & 312 & 375 & 123 & 221 & 146 & 4549 & \\
\hline & Total (\%) & 3.65 & 6.64 & 9.34 & 13.87 & 16.60 & 20.27 & 3.76 & 6.86 & 8.24 & 2.70 & 4.86 & 3.21 & & \\
\hline
\end{tabular}


On the basis of the habit of plants, the identified types were further classified into arboreal (trees) and non-arboreal (herbs, shrubs and undershrubs) pollen types (Table 2). The non-arboreal type of pollen grains $(59.16 \%)$ dominated the air of the location, while the arboreal pollen type contributed with an average of 23.94 per cent.

Table 2. Incidence of airborne pollen grains based on habit of plants.

\begin{tabular}{lccccc}
\hline Month & Arboreal & Non-arboreal & Unidentified & Total & Total (\%) \\
\hline October & 22 & 114 & 30 & 166 & 3.65 \\
November & 47 & 185 & 70 & 302 & 6.64 \\
December & 49 & 331 & 45 & 425 & 9.34 \\
January & 100 & 395 & 136 & 631 & 13.87 \\
February & 264 & 387 & 104 & 755 & 16.60 \\
March & 375 & 391 & 156 & 922 & 20.27 \\
April & 43 & 105 & 23 & 171 & 3.76 \\
May. & 46 & 210 & 56 & 312 & 6.86 \\
June & 74 & 270 & 31 & 375 & 8.24 \\
July & 20 & 70 & 33 & 123 & 2.70 \\
August & 20 & 154 & 47 & 221 & 4.86 \\
September & 29 & 79 & 38 & 146 & 3.21 \\
\hline Total count & 1089 & 2691 & 769 & 4549 & \\
Total (\%) & 23.94 & 59.16 & 16.90 & & \\
\hline
\end{tabular}

Among the arboreal, non-arboreal and unidentified pollen grains, the non-arboreal pollen type was recorded to be the highest in January, gradually increased from October and then became steady up to March, which gradually declined drastically in the subsequent months. The arboreal and the unidentified pollen types were highest in March, which also gradually increased from October, but drastically declined in the subsequent months without any steady trend (Fig. 1).

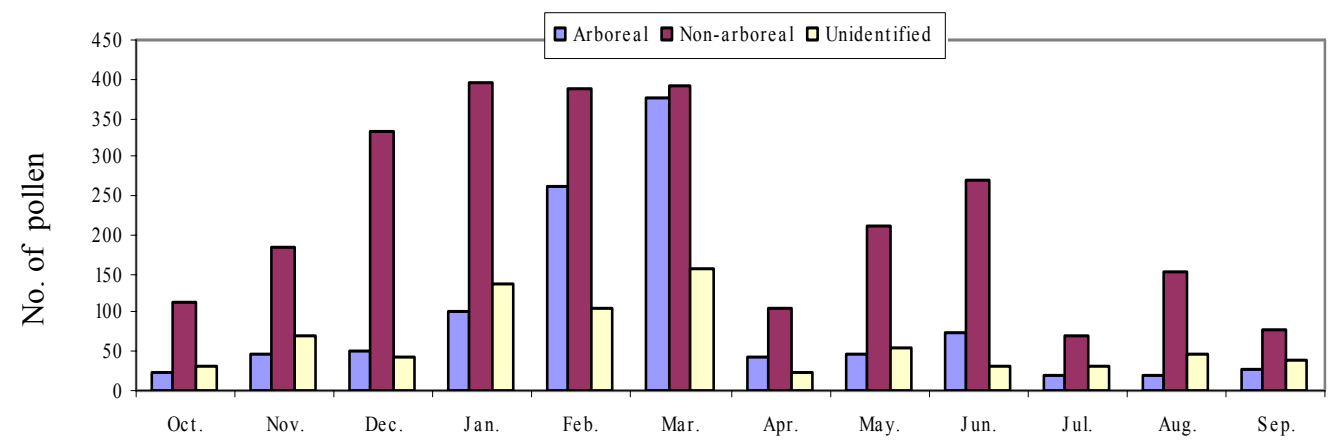

Fig. 1. Monthly variation of airborne pollen count on the basis of habit of plants.

When all habit types are considered maximum pollen concentration was observed in the month of March with a total of 922 pollen grains $(20.27 \%)$, followed by February with a total of 755 pollen grains $(16.60 \%)$ and January with a total of 631 pollen grains $(13.87 \%)$. The incidence 
was minimum in the month of July (2.70\%), followed by September (3.21\%), October (3.65\%) and April (3.76\%), (Tables 1 and 2).

Poaceaeous pollen type appeared in air throughout the year in varying concentrations (Table 1). The Cyperaceae, Amaranthaceae, Mimosaceae, Cocos nucifera, Asteraceae and Caesalpiniaceae pollen were also found to appear in air throughout the year except a few months. The pollen of Mesua nagassarium, Cocos nucifera, Embelica officinalis, Mikania scandens, Butea monosperma, Cassia siamea, Acacia auriculiformis, Pinus sp. were found to be of seasonal appearence. When the synaptical seasons are considered then it was observed that the winter (January, February and March) was the most dominated season, when the pollen concentration was maximum (50.74\%). In this season, steady increase in the incidence of pollen grains was observed with a climax at the end (March), which showed the highest peak when all other seasons were considered. The next dominant peak was the post-monsoon season (October, November and December). With the beginning of this season (October), minimum occurrence of pollen grains was observed, then gradually being increased with the rolling of the season, when it was maximum at the end (December). The pre-monsoon period (April, May and June) also showed such features but with less number than the post-monsoon season. With the beginning of monsoon season (July), the incidence of pollen grains drastically decreased and seemed to be minimum compared to other seasons (Fig. 2).

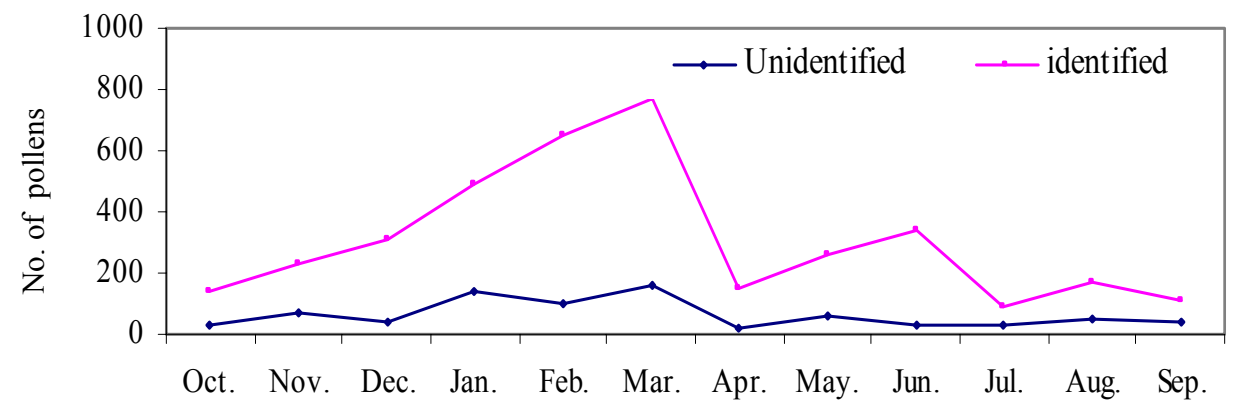

Fig. 2. Monthly incidence of identified and unidentified airborne pollen grains.

When the result was compared with the Badya (1989) at the same location, a total of 36 pollen types were trapped and classified into 22 families, where Poaceae contributed the highest number of pollen grains $(40.53 \%)$, followed by Amaranthaceae (8.85\%), Arecaceae $(7.79 \%)$, Asteraceae (4.78\%), Artocarpus sp. (4.21\%), Cyperaceae (4.04\%) and others. Some monthly incidences were also observed differences.

A pollen calendar is required for depicting the incidence of pollen grains of an area at a glance and to understand the whole of the airborne pollen spectrum of the year as well as their range of occurrences. A pollen calendar of this specific area is presented in Fig. 3. Some of the pollen types showed greater range of flowering period than others. The pollen type which showed flowering throughout the year was Poaceae type. Relatively, other greater range of flowering periods were showed by types of Cyperaceae, Amaranthaceae, Mimosaceae, Cocos nucifera, Asteraceae and Caesalpiniaceae. Some other types showed a very shorter range of flowering period and they were types of Amaranthus viridis, Pinus sp., Adhatoda vasica, Bombax insigne and Moringa oleifera (Table 1, Fig. 3). When categorized in terms of pollen groups, in October'06 to September'07, non-arboreal type contributed the highest number (59.16\%) than arboreal type (23.94\%) of the total pollen types trapped and analysed. 
Despite all attempts for proper identification, $16.90 \%$ of the pollen grains remained unidentified (Tables 1-2). Some of these pollen grains appeared to have been distorted and disfigured making it difficult to identify. However, the incidence of unidentified types, in relation to identified ones, showed same pattern of their monthly occurrences (Fig. 2). The identified pollen grains showed their highest incidence in the month of March and lowest in July.

\begin{tabular}{|c|c|c|c|c|c|c|c|c|c|c|c|c|}
\hline \multirow{2}{*}{ Pollen types } & \multicolumn{12}{|c|}{ Month } \\
\hline & Oct. & Nov. & Dec. & Jan. & Feb. & Mar. & Apr. & May. & Jun. & Jul. & Aug. & Sep. \\
\hline Pinus sp & & & & & & & & & & & & \\
\hline Acacia auriculiformis & & & & & & & & & & & & \\
\hline Acacia catechuoides & & & & & & & & & & & & \\
\hline Amaranthus spinosus & & & & & & & & & & & & \\
\hline Artocarpus heterophyllus & & & & & & & & & & & & \\
\hline Cassia siamea & & & & & & & & & & & & \\
\hline Cocos nucifera & & & & & & & & & & & & \\
\hline Embellica officinalis & & & & & & & & & & & & \\
\hline Mesua nagassarium & & & & & & & & & & & & \\
\hline Samanea saman & & & & & & & & & & & & \\
\hline Amaranthaceae & & & & & & & & & & & & \\
\hline Arecaceae & & & & & & & & & & & & \\
\hline Asteraceae & & & & & & & & & & & & \\
\hline Caesalpinaceae & & & & & & & & & & & & \\
\hline Cyperaceae & & & & & & & & & & & & \\
\hline Euphorbiaceae & & & & & & & & & & & & \\
\hline Lamiaceae & & & & & & & & & & & & \\
\hline Mimosaceae & & & & & & & & & & & & \\
\hline Poaceae & & & & & & & & & & & & \\
\hline Unidentified & & & & & & & & & & & & \\
\hline Amount in number & & & $0-20$ & & & & & $21-200$ & & & & Above 201 \\
\hline
\end{tabular}

Fig. 3. Airborne pollen calendar for Chittagong University Campus.

The differences that are observed between the two months surveys in the same place may be due to vegetational and meteorological changes of the location. Moreover, trapping methods and variation of scanning the exposed area of the slides, may be the other possible causes for the 
differences. But, in both the studies, pollen grains from Poaceae came out to be the dominant. In the present study, maximum contribution was made by Poaceae and Cyperaceae. Altogether, 13 pollen types were found to be common in both the surveys. In this study a total of 21 newly identified pollen types in the air of Chittagong University Campus were recorded which are Acacia auriculiformis, Acacia catechuoides, Albizia lebbeck, Adhatoda vasica, Amaranthus spinosus, Artocarpus heterophyllus, Amaranthus viridis, Barringtonia acutangula, Bombax insigne, Butea monosperma, Cocos nucifera, Kyllinga monocephala, Chenopodium album, Citrus spp., Mangifera indica, Mesua nagassarium, Moringa oleifera, Mikania scandens, Samanea saman, Ixora spp. and Pinus spp. These species are observed to be intensely planted during the last two decades which are now at maturity and blooming stage. Leticia and Angeles (2005) also recorded 45 per cent Poaceae as dominant pollen type from Uruguay, where in total 76 pollen types were recorded. Boral et al. (2004) in the same way recorded 31 types from West Bengal, India.

Variation was also observed between the pollen calendars of both the studies. In the present pollen calendar, only Poaceae type of pollen showed flowering throughout the survey while in the previous one, Poaceae along with several others like Amaranthaceae, Arecaceae, Asteraceae, Cyperaceae and Tridax procumbens types of pollen grains showed flowering throughout the year with some differences of very shorter range of flowering.

Recio et al. (2006) observed maximum pollen occurrence from February to June from Southern Spain. But Boral et al. (2004) observed maximum pollen concentration from March to May in the air of West Bengal, India. Vergamini et al. (2006) reported minimum pollen concentration in October from Brazil, which is found to be dissimilar with the present study. They reported 29 types of arboreal pollen grains from Brazil. Katelaris and Burke (2003) reported maximum arboreal pollen concentration in August and non-arboreal in October from Sydney, Australia.

Bhat and Rajasab (1985) in India observed 42 types of pollen grains, where they identified almost all the types. In their survey, Poaceae (56\%) and Parthenium (21.4\%) pollen count was the highest, covering about three/fourth of the total pollen count, indicating the occurrence of abundance of particular type of non-arboreal wild plants. Although, the incidence of high amount of Poaceaeous pollen grains throughout the world (Hyde 1959, El-Ghazaly et al. 1993, Zaursza et al. 1993, Alson and Hurtado 1990) is a common phenomenon, the occurrence of Parthenium pollen type was remarkable in that area.

The pollinosis period identified in this survey will be highly useful for detection and treatment of allergenic problems prevailing in a systematic and target oriented treatments. Monoculture of these types of plants are frequent which will cause serious health problems in future. Investigation in this line is very urgently needed.

This survey also indicated the occurrence and prevalence of anemophilous flowers in the area. Although, it is generally considered that anemophillous plants are usually airborne in nature, yet some of the entomophilous pollen grains are also found to be airborne. These are Bombax insigne and Citrus spp. The phenological patterns of all these airborne pollen producing plants are also identified through this study. It is to be mentioned here that the phenophase of the set of plants of an area is mostly dependent on the atmospheric parameters along with seasons. For this reason the variation of one study area is due to variation of floral composition along with the seasonal and meteorological variations. At the same time, any observed pollen incidence at any place may change qualitatively and quantitatively with the years to come (El-Ghazaly et al. 1993). 


\section{References}

Alson, J. and I. Hurtado, 1990. Air pollen dispersal in a tropical area. Aerobiol. 6:122-127.

Badya, K.K. 1989. Palynomorph and Airborne Pollen Spore Survey of Chittagong. M.Sc. Thesis, Department of Botany, Chittagong University, Chittagong.

Badya, K.K. and M.K.Pasha. 1991. A pollen calendar for Chittagong University Campus, Chittagong (Bangladesh). Aerobiol. 7(1): 62-68.

Bhat, M.M. and A.H. Rajasab, 1985. Incidence of airborne pollen at two different locations. Ind. J. Med. Res. 82: 346-352.

Boral, D., S. Chatterjee and K. Bhattacharya. 2004. The occurrence and allergic potential of airborne pollen in West Bengal, India. Ann. Agric. Environ. Med. 11: 45-52.

El-Ghazaly, G., P.K. El-Ghazaly, K.A. Larson and S. Nilsson, 1993. Comparison of airborne pollen grains in Huddinge and Stockholm. Aerobiol. 9: 53-68.

Gregory, P.H. 1961. The Microbiology of the Atmosphere. Leonard Hill and Co., London, pp. 251.

Hyde, H.A. 1959. Volumetric counts of pollen grains at Cardiff, 1954-1957. J. Allergy 30: 219-234.

Katelaris, C.H. and T.V. Burke. 2003. A 7- year pollen profile of major Olympic Games venues in Sydney, Australia. Aerobiol. 19: 121-124.

Leticia, T. and B. Angeles. 2005. First volumetric airborne pollen sampling in Montevideo city, Uruguay. Aerobiol. 21: 33-41.

Pasha, M.K. 2003. Aerobiology. In: Banglapedia Vol. 3. S. Islam, S. Miah, W. Ahmed, A.M. Chowdhury, S.M.M. Rahman, K. Siddiqui and S.M.H. Kabir (Eds.). Asiatic Society of Bangladesh. p. 52.

Recio, M., M.M. Trigo, F.J. Toro, J.J. Garcia-Gonzalez and B. Cabezudo. 2006. A three year aeropalynological study in Estepona (Southern Spain). Ann. Agric. Environ. Med. 13: 201-207.

Vergamini, S.M., R.M.B.C.A., Valencia-Barrera, C.P. Morales and D. Fernandez-Gonzalez. 2006. Atmospheric pollen survey in Brazil. Aerobiol. 22(2): 20-23.

Zaursza, E.B., B. Samolisski, B. Tarchalska and P. Rapiejko. 1993. Allergenic pollen and pollinosis in Warsaw. Aerobiol. 11: 47-51.

(Manuscript received on 22 June, 2008; revised on 21 March, 2009) 